\title{
IAMJ
}

INTERNATIONAL

AYURVEDIC

MEDICAL JOURNAL

\section{A REVIEW ON AN ENDANGERED HIMALAYAN MEDICINAL AROMATIC PLANT - CHORAKA (ANGELICA GLAUCA EDGEW)}

\author{
Sangeetha G. Pillai ${ }^{1 *}$, Yadevendra Yadav ${ }^{2}$, Khem Chand Sharma ${ }^{3}$ \\ ${ }^{1} \mathrm{PG}$ Scholar, ${ }^{2}$ Assistant Prof., ${ }^{3} \mathrm{HOD}$ and Professor \\ Department of Rasashastra and Bhaishajyakalpana, Rishikul Campus, Uttarakhand Ayurved University, \\ Haridwar, Uttarakhand, India
}

Corresponding Author: sangee987@gmail.com

https://doi.org/10.46607/iamj3408092020

(Published online: September 2020)

Open Access

(C) International Ayurvedic Medical Journal, India 2020

Article Received: 27/08/2020 - Peer Reviewed: 08/09/2020 - Accepted for Publication: 08/09/2020

Check for updates

\begin{abstract}
Choraka is a highly valued aromatic plant endemic to the Himalayan region. Angelica glauca is a perennial herb of Umbelliferae family. It is very commonly used as a spice and for treating stomach ailments. Its essential oil is highly valued and has broncho-relaxant, antimicrobial, antifungal, anxiolytic and antioxidant activity. Its chemical constituents are mainly (Z)-ligustilide, (Z)-butylidenephthalide, and (E)-butyl idenephthalide. It has been in use since the period of Arthashastra and references can also be seen in Brihatrayi and various Nighantus for Mukha and Nasa roga chikitsa. Ruthless uprooting of the plant from its natural habitat for its sale in the market has led to a considerable decline in its availability. This article deals with its distribution, its uses in Ayurveda with classical references, researches on its extracts, controversies and the threats faced by the plant.
\end{abstract}

Keywords: aromatic, broncho-relaxant, choraka, endangered, essential oil, himalayas

\section{INTRODUCTION}

The Himalayan Range has always been of utmost importance to India. It is a spiritual abode, a border, a protective cover, reason for rainfall and replenishment of the River system of India. Ayurveda has considered the Himalayas as best among Aushadha bhoomi. This article deals with a Himalayan drug, Choraka aka Choru in the local language. Choraka i.e. Angelica glauca Edgew. of Umbelliferae / Apiaceae family, is a 
critically endangered Himalayan perennial herb which has been included in IUCN red list (2013) ${ }^{1}$. Its aromatic and medicinal value is so immense that it is considered as one of the top three prioritized medicinal plants of Western Himalaya. ${ }^{2}$ It is usually distributed at altitudes of 2000-4000 meters world-wide ${ }^{3}$ with height ranging between 1.2 to 3.6 meters, having tuberous roots (20-50 $\mathrm{cm}$ thick and spongy). In the Indian sub-continent, it is an endemic medicinal plant of the Himalaya, which is distributed in Uttarakhand, Jammu \& Kashmir and Himachal Pradesh. ${ }^{4}$ As the roots and seeds of Choraka are aromatic, they are used as a condiment and spice in hills and also as a flavoring agent in various food items. Local people use oil extracted from dried roots of Choraka for massage. They utilize its roots for preparation of local alcoholic drink for personal medicinal use. The roots are also used in the preparation of gin and the liqueurs known as bitters. ${ }^{5}$ Choraka is collected by inhabitants of Western Himalaya from wild habitat as a source of food and medicine and is sold at the local and national level due to its huge market and medicinal value. The unsustainable practice of uprooting the whole plant while collecting Choraka from its natural habitat has placed it in the list of critically endangered plants of the Himalayas. Researches have been performed for its in situ and ex situ conservation. ${ }^{6}$ The aroma of Choraka is pungent with a sweet-bitter taste. The roots yield a pale to brownish-yellow essential oil. Roots can be collected and dried during SeptemberOctober. $^{7}$

\section{Uses}

The roots are known to be cardioactive and stimulant. Due to their carminative action, these are useful in stomach ailments of adults and children. These are expectorant, diaphoretic; and also used in rheumatism and urinary disorders. ${ }^{8}$ The powdered roots mixed with cow's milk are used to treat bronchitis. ${ }^{9,10}$ These are also used to cure bilious complaints, menorrhagia, infantile atrophy and rinderpest. ${ }^{11}$ Recently, the popularity of Angelica has increased much in the United States. It is often acclaimed by herbalists as a treatment for flatulence, stomach pains and as a stimulant to stimulate circulation and warm the body. ${ }^{12}$

\section{Choraka in Classics}

\begin{tabular}{|c|c|}
\hline \multicolumn{2}{|l|}{ Pre Samhita Kaala } \\
\hline Kautilya's Arthashastra & $\begin{array}{l}\text { - Kautilya has referred Choraka as a type of spice and has included it in Tikta varga in } \\
\text { Chapter } 15 \text { of Arthashastra dealing with The Superintendent of Storehouse. }{ }^{13}\end{array}$ \\
\hline \multicolumn{2}{|l|}{ Samhita Kaala } \\
\hline Susruta Samhita & $\begin{array}{l}\text { - Classified Choraka in Eladi gana as Chanda. Dalhana has commented it as Choraka } \\
\text { bheda. }{ }^{14} \\
\text { - Mentioned Choraka as Taskara in making Anuvasana basti. }{ }^{15} \\
\text { - Mentioned as Tilaparnika (Commented as Choraka by Dalhana) which is used for making } \\
\text { Krtanna. }^{16}\end{array}$ \\
\hline Charaka Samhita & $\begin{array}{l}\text { - Included Choraka under Sanjnasthapana mahakashaya. }{ }^{17} \text { Charaka has used Choraka in } \\
\text { various external applications for Kushta, Shirashoola }{ }^{18} \text { and Sheeta nashana. Here word } \\
\text { Chanda is used instead of Choraka and is clarified by commentators Chakrapani and } \\
\text { Yogendranath Sen. }{ }^{19} \\
\text { - Mentioned in fumigation of clothes, bedsheets and beds in Kumaragara with ghee. }{ }^{20} \\
\text { - Content of Maha Paishachika Ghrta in Unmada. }{ }^{21} \text { Ghrta made with Choraka has been } \\
\text { - It is also being used as a Taila for Abhyanga, as a Dhoopana dravya }{ }^{24} \text { and also for } \\
\text { - Utsadana }{ }^{25} \text { in Apasmara. } \\
\text { - An ingredient in Shatyadi Churna in Hikka Shwasa Chikitsa. }{ }^{26} \\
\text { - Its Kashaya is used for making Utkarika in Madana Kalpa. }{ }^{27}\end{array}$ \\
\hline
\end{tabular}




\begin{tabular}{|c|c|}
\hline & $\begin{array}{l}\text { - } \quad \text { It is mentioned along with Dhamargava for Vamana in Manovikara. }{ }^{28} \\
\text { - } \quad \text { Mentioned in Snehapana Vyapat. }{ }^{29}\end{array}$ \\
\hline $\begin{array}{l}\text { Ashtanga Sangraha \& } \\
\text { Ashtanga Hridaya }\end{array}$ & $\begin{array}{l}\text { - Ashtanga Hridaya has included Choraka under Eladi Gana. Arunadatta and Hemadri have } \\
\text { commented it as Granthiparna. }{ }^{30} \\
\text { - } \quad \text { It is used for inhalation in Pratishyaya in Nasaroga Pratishedha. }{ }^{31,32}\end{array}$ \\
\hline Kasyapa Samhita & - $\quad$ Choraka is mentioned along with other drugs for Dhoopana in Moha. ${ }^{33}$ \\
\hline \multicolumn{2}{|l|}{ Nighantu Kaala } \\
\hline $\begin{array}{l}\text { Dhanvantri } \\
\text { Nighantu }^{34}\end{array}$ & - Chandanadi varga \\
\hline Madanapala Nighantu & - Karpooradi varga \\
\hline Sodhala Nighantu ${ }^{35}$ & - $\quad$ Chandanadi varga \\
\hline Raja Nighantu & - $\quad$ Chandanadi varga \\
\hline Kaiyadeva Nighantu ${ }^{36}$ & - Aushadhi Varga \\
\hline Saligrama Nighantu ${ }^{37}$ & - $\quad$ Karpuradi varga \\
\hline Nighantu Adarsa & - $\quad$ Eladi gana \\
\hline Bhavaprakasha Nighantu & - $\quad$ Karpooradi varga \\
\hline Abhidhanamanjarai $^{38}$ & $\begin{array}{l}\text { - Madanadi gana in Eladi Varga CH 31, As a synonym of Shathi and as synonym of Chanda } \\
\text { - } \quad \text { In Shookadhanyadi varga as Sarvoushadhi varga } \\
\text { - Shati, Swetha Karpoora and Choraka are known as Ugra in Sankeerna varga in Tryartha } \\
\quad \text { Varga. }\end{array}$ \\
\hline Abhidhanaratnamala ${ }^{39}$ & - $\quad$ Katu skandha \\
\hline Ashtanganighantu 40 & - Eladigana \\
\hline Madanadi nighantu ${ }^{41}$ & - $\quad$ Eladi ganam \\
\hline Saraswati Nighantu ${ }^{42}$ & - $\quad$ Chandanadi Varga \\
\hline Sousrutha Nighantu ${ }^{43}$ & - $\quad$ Eladi gana \\
\hline
\end{tabular}

\section{Rasa panchaka according to different nighantus:}

\begin{tabular}{|c|c|c|c|c|c|}
\hline Nighantu & Rasa & Guna & Veerya & Vipaka & Karma \\
\hline $\begin{array}{l}\text { Dhanwantari } \\
\text { Nighantu }\end{array}$ & Tikta & & & & $\begin{array}{l}\text { Visharaktantakaraka, Kushta Kanduhara, } \\
\text { Vranahara, Krimihara, Vatahara }\end{array}$ \\
\hline Raja Nighantu 4 & Tikta & & Ushna & & $\begin{array}{l}\text { Vata kaphahara, Nasa mukha rogahara, Krimi } \\
\text { hara, Rujahara, Ajeernahara }\end{array}$ \\
\hline $\begin{array}{l}\text { Kaiyyadeva } \\
\text { Nighantu }\end{array}$ & $\begin{array}{l}\text { Madhura, } \\
\text { Tikta, Katu }\end{array}$ & $\begin{array}{l}\text { Laghu, } \\
\text { Tikshna }\end{array}$ & & Katu & $\begin{array}{l}\text { Hrdya, Kushtahara, Kanduhara, Kaphava- } \\
\text { tahara, Rakshoghna, Swedahara, Medohara, } \\
\text { Raktaja vikarahara, Jwarahara, Gandhahara, } \\
\text { Vishahara, Vranahara }\end{array}$ \\
\hline $\begin{array}{l}\text { Madanapala } \\
\text { Nighantu }^{45}\end{array}$ & Madhura & Laghu & Sheeta & & Kushtahara, Vata kaphahara, Asrajith \\
\hline $\begin{array}{l}\text { Shaligrama } \\
\text { Nighantu }\end{array}$ & $\begin{array}{l}\text { Madhura, } \\
\text { Tikta }\end{array}$ & $\begin{array}{l}\text { Laghu, } \\
\text { Tikshna }\end{array}$ & & Katu & $\begin{array}{l}\text { Hrdya, Vata vikarahara, Kandu Kushtahara, } \\
\text { Kaphahara, Swedahara, Twak doshahara, } \\
\text { Vranahara, Medohara, Rakta doshahara, } \\
\text { Mukha Nasarujahara, Krmharai, Ajeernaha- } \\
\text { ra, Daurgandhyahara, Alakshmi nashanam }\end{array}$ \\
\hline
\end{tabular}




\section{Controversy:}

Bhavaprakasha Nighantu has included Choraka (Bhateur) under Karpooradi Varga. He mentions it as a controversial drug and as a variety of Granthiparna. Some have considered Sthouneyaka and Choraka as the same plant. ${ }^{46}$

\section{Choraka in Ayurveda}

Synonyms: Taskarah, Kshemaka, Chanda, Ripu, Kitava, Ganahasa, Kopanaka, Dushpatra, Shankhanika, Phalachoraka, Shukla, Ardrakanda, Granthikeshi, Keshini, Nishachari, Kshemika, Dhanya, Dhanavati, Vernacular name: Choru, Gandrayan (Hindi), Choraka Pullu (Malayalam), Gaddi Davanamu (Telugu) . Properties and Action ${ }^{47}$ Rasa: Madhura, Katu, Tikta, Guna: Laghu, Ruksha, Tikshna, Virya: Usna Vipaka: Katu, Karma: Vatahara, Kaphahara, Medohara, Hrdya, Samjnasthapana, Dipna, Pachana, Varnaprasadana, Vamaka Dose: 3 - 6 gms

Important Formulations: Guduchyadi modaka, Bala ashwagandhadi lakshadi taila, Maha narayana taila. It has been mentioned as Sheeta veerya in Kaiyyadeva Nighantu and Dhanwantari nighantu, but Ushna veerya in Raja nighantu. API has accepted it as Ushna veerya.

\section{Chemical constituents:}

$80 \%$ methanol extract of dried roots of plant: (Z)Lingustilide $\mathrm{C}_{12} \mathrm{H}_{14} \mathrm{O}_{2}$, (Z)Butylidinephthalide $\mathrm{C}_{12}$ $\mathrm{H}_{12} \mathrm{O}_{2}$, Methyl Octadecadionate $\mathrm{C}_{19} \mathrm{H}_{24} \mathrm{O}_{2}$, Caryophyllene $\mathrm{C}_{15} \mathrm{H}_{24}$, Caryophyllene Oxide $\mathrm{C}_{15} \mathrm{H}_{24} \mathrm{O} .{ }^{48}$ Essential oil: The essential oil of root is a pale yellow to a deep amber liquid having warm, pungent, and spicy odour with musty/earthy top note and bittersweet flavour. The yield of roots ranges from 0.3- 0.4 $\%$. Whole plant Hydrodistillation: phellandrene (18.0\%), pinene (14.0\%), trans-carveol (16.4\%), caryophyllene (8.6\%), and caryophyllene oxide $(8.0 \%) .{ }^{50}$ Aerial parts Hydrodistillation;- phellandrene (13.5\%), trans-carveol (12.0\%), pinene (11.7\%), thujene $(7.5 \%)$, caryophylleneoxide $(7.2 \%)$, caryophyllene $(7.0 \%)$, terpinene $(6.7 \%)$, nerolidol $(6.5 \%)$, and bisabolene $(5.2 \%)^{51}$. Root Hydrodistillation; (Z)ligustilide (40.6-53.0\%), (Z)-butylidenephthalide (20.7-32.8\%), and (E)-butylidenephthalide (2.5$5.9 \%)^{52}$

\section{Pharmacological activities}

1. Broncho relaxation: On evaluation of bronchorelaxant activity of A. glauca essential oil in histamine and ovalbumin (OVA)-induced broncho constriction in guinea pigs and mice respectively, it was found that its oral treatment $(200 \mu \mathrm{L} / \mathrm{kg})$ significantly increased the latency for PCT in histamine-induced guinea pigs suggesting bronchodilating activity of $A$. glauca oil against histamine. Oral treatment of A. glauca oil significantly ( $\mathrm{P}<$ 0.001) decreased absolute blood eosinophil count, serum level of IgE and the number of eosinophils, neutrophils in BALF. ${ }^{53}$

2. Antioxidant activity: IC50 value $32.32 \mu \mathrm{g} / \mathrm{mL}$ of A. glauca oil exhibited considerable free radical scavenging activity. When DPPH scavenging activity of the oil was compared with synthetic antioxidant BHT, the oil provided weaker activity.

3. Antimicrobial activity: A sensitivity ordering of Escherichia coli $>$ Staphylococcus aureus $>$ Pasturella multocida $>$ Bacillus subtilis was seen when oil of $A$. glauca was set for testing its antimicrobial activity. Overall, A. glauca oil possessed antibacterial activity comparable with the standard drug, Amoxycillin.

4. Antifungal activity: Antifungal activity of oil from A. glauca was comparable with the standard drug (flumequinene). The order of sensitivity of selected fungal strains are Microsporum canis $>$ Fusarium solani $>$ Candida albicans $>$ Aspergillus flavus.

5. Phytotoxic activity: The essential of oil of $A$. glauca shows good in vitro phytotoxic activity against Lemana minor. Six coumarins from $A$. glauca are reported by Saeed and Sabir that possess potential irritant and cytotoxic activities.

6. Anxiolytic activity: Methanolic extract of A. glau$c a$ was studied at graded doses to evaluate its anxiolytic activity which was assessed by behavioural observations conducted through elevated plus maze, open field and hole-board test and equated with control and standard control. Results showed that $A$. glauca possesses anxiolytic property. 


\section{Limiting Factors}

Currently, Choraka products are standardized and packaged and are available as crude plant parts (dried roots, stems, and seeds), or as semi-purified preparations (crude extracts, essential oils, and powder). Its dried rhizome is priced around Rs. 1500 per $\mathrm{kg}$; and seeds are sold at a much higher price in Uttarakhand. In Himachal Pradesh, the turnout of A. glauca during was reduced from 9 tons (2002-2003) to 0.2 (20032004) ton indicating a rapid loss of this species in the wild. The excessive grazing by heavy body animals (buffalos, cows, and mules) has led to excessive soil erosion, destruction of natural vegetation, and its conversion into artificial grasslands. The peak grazing period of sub-Alpine and Alpine region is from May to September when in addition to local livestock, the migratory community (Gujjar) also goes in the region for grazing. This period corresponds to that of growth and seed maturation period of A. glauca. Therefore, in order to conserve the plant, there should be a balance between grazing in alpine areas and management of MAPs $^{54}$. The economic viability of cultivation of $A$. glauca has also been assessed by benefit-cost ratio and was found that its cultivation could act as an additional source of income to the farmers, especially if they make their own vermicompost for its growth. ${ }^{55}$

\section{DISCUSSION}

Choraka is a medicinal, aromatic plant with limited distribution to those of the Himalayas. Though it has many medicinal properties, on close examination, it can be noticed that it works mainly on Pranavaha srotas and Annavaha srotas. Its Ushna veerya and Katu vipaka makes it Vata kaphahara and Medohara. It can also be seen that its Gandhatva (Prithvi mahabhoota) is utilized more in its uses. It is reflected in its Samnjasthapana and Dourgandhyahara property. Its aromatic property also supports its use in Fumigation, Inhalation and Rakshoghna karma. While assessing the Vargeekarana in Nighantus, it can be seen that it is included under aromatic groups like Chandanadi Varga, Karpooradi varga and Eladi varga. Its aroma has led to the utilization of its essential oils with an average yield of $0.3-0.4 \%$. Researches have been done, and much more has to be done in this direction. Its anti-microbial and antifungal activity may be the reason for its use in fumigation and inhalation. Its Broncho relaxant activity corresponds to its use in Mukha nasa roga. Its anxiolytic activity supports its use in Unmada and Apasmara. Although it is a plant with high medicinal value, the Ayurveda community is facing a shortage in its availability. Unscrupulous uprooting, grazing and availability of less suitable time for cultivation due to extremities of climate in the Himalayas have led to its inclusion in the endangered plant list. Studies are being conducted for its conservation and in vitro, in situ cultivation. Cultivation of Choraka by Himalayan farmers may also increase their income as it is highly priced in the market. Promoting agriculture can also help in meeting its increasing demand in Ayurveda medicine manufacturing industry.

\section{CONCLUSION}

Choraka is a high-value plant with a variety of uses in medicine and perfumery. A balance between its cultivation and usage has to be maintained to prevent it from being extinct. More researches have to be done in its antipyretic action and its effects in skin disorders which have not been explored much even though it is mentioned in Nighantus.

\section{REFERENCES}

1. Bown. D. (1995): Encyclopedia of Herbs and their Uses. Dorling Kindersley, London. ISBN 0-7513-020-31.

2. Sastry, A. R. K., \& Chatterjee, S. (2000). Prioritization of medicinal plants of India. Setting biodiversity conservation priorities for India, 2, 467-473

3. Butola JS, Vashistha RK; An overview on conservation and utilization of Angelica glauca Edgew. in three Himalayan states of India. Medicinal plants, 2013; 5 (3): 171-8.

4. Butola, J. S.; Badola, H. K. Effect of Pre-sowing Treatment on Seed Germination and Seedling Vigour in Angelica Glauca, a Threatened Medicinal Herb. Curr. Sci. 2004, 87(6), 796-799.

5. Purohit S. S, Sharma AK, Prajapati N D, Kumar T. (2209), A handbook of medicinal plants: a complete source book.2:3523

6. https://himalayanwildfoodplants.com/2020/01/angelicaglauca-edgew-chora-

$\%$ E0\%A4\%9A\%E0\%A5\%8B\%E0\%A4\%B0\%E0\%A4\%BE/

7. R. Vashistha, B. P. Nautiyal and M. C. Nautiyal. Conservation status and morphological variations between populations of Angelica glauca Edgew. and Angelica archangelica Linn. In Garhwal Himalaya. High Altitude Plant Physiology Re- 
search Centre, HNB Garhwal University, Srinagar (Garhwal) 246 174, India

8. Anon; The wealth of India. A Dictionary of Indian Raw Materials and Industrial Products. Vol. I: (revised); 1985. p 2756.

9. Sarker SD, Nahar L; Natural medicine: the genus Angelica. Curr Med Chem., 2004; 11 (11): 1479-500.

10. Gaur RD; Flora of the District Garhwal North-West Himalaya (With Ethnobotanical notes). Transmedia: Srinagar (Garhwal); 1999.)

11. Chopra, R. N., \& Nayar, S. L. (1982). Chopra, 1. C.(1956) Glossary of Indian Medicinal Plants. Council of Scientific and Industrial Research, New Delhi, 164.

12. Jeevan Chandra et al., Behavioral effects of high-altitude medicinal plant in rats, Sch. Acad. J. Pharm., Sep 2016; 5(9):377-382

13. https://www.wisdomlib.org/hinduism/book/kautilyaarthashastra/d/doc366061.html

14. Acharya Susrutha, Hindi Translation of Commentary by Dalhana Achraya and Gayadasa Acharya,Translatred by Dr Keval Krishna Thakral, Chaukhambha Orientalia, Varanasi, Part 1, Sutra stana, Chapter 38, Shloka 25, Pg 419

15. Acharya Susrutha, Hindi Translation of Commentary by Dalhana Achraya and Gayadasa Acharya,Translatred by Dr Keval Krishna Thakral, Chaukhambha Orientalia, Varanasi, Part 2, Chikitsa sthana, Chapter 37, Shloka 27, Pg 550

16. Acharya Susrutha, Hindi Translation of Commentary by Dalhana Achraya and Gayadasa Acharya,Translatred by Dr Keval Krishna Thakral, Chaukhambha Orientalia, Varanasi, Part 1, Sutra stana, Chapter 46, Shloka 221, Pg 594

17. Agnivesa, Charaka Samhita, elaborated by Charaka and Drdhabala, With Ayurveda Deepika Commentary by Chakrapanidatta, Edited By Vaidya Yadavji Trikamaji Acharya, Sutra sthana, Chapter 4, shloka 48, Published by Satyabhamabai pandurang,For the Nirnaya Sagar Press, Bombay, Third edition, Pg No 34

18. Agnivesa, Charaka Samhita, elaborated by Charaka and Drdhabala, With Ayurveda Deepika Commentary by Chakrapanidatta, Edited By Vaidya Yadavji Trikamaji Acharya, Sutra sthana, Chapter 3, shloka 24, Published by Satyabhamabai pandurang, For the Nirnaya Sagar Press, Bombay, Third edition, Pg No 29

19. Agnivesa, Charaka Samhita, elaborated by Charaka and Drdhabala, With Ayurveda Deepika Commentary by Chakrapanidatta, Edited By Vaidya Yadavji Trikamaji Acharya, Sutra sthana, Chapter 3, shloka 24,28,8, Published by Satyabhamabai Pandurang, For the Nirnaya Sagar Press, Bombay, Third edition, Pg No 28, 29.

20. Acharya Charaka, Charaka Samhitha, Shareera sthana, with Vidyotini commentary by Pandit Kashinath Pandey and Dr Gorakhnath Chaturvedi (Part 1), Reprint 2015, Chaukhamba Bharathi Academy, Varanasi,Chapter 8, Shloka 61, Page 660

21. Agnivesa, Charaka Samhita, elaborated by Charaka and Drdhabala, With Ayurveda Deepika Commentary by Chakrapanidatta, Edited By Vaidya Yadavji Trikamaji Acharya, Chikitsa sthana, Chapter 9, shloka 45, Published by
Satyabhamabai Pandurang, For the Nirnaya Sagar Press, Bombay, Third edition, Pg No 472.

22. Agnivesa, Charaka Samhita, elaborated by Charaka and Drdhabala, With Ayurveda Deepika Commentary by Chakrapanidatta, Edited By Vaidya Yadavji Trikamaji Acharya, Chikitsa sthana, Chapter 9, shloka 57, Published by Satyabhamabai Pandurang, For the Nirnaya Sagar Press, Bombay, Third edition, $\mathrm{Pg}$ No 472.

23. Agnivesa, Charaka Samhita, elaborated by Charaka and Drdhabala, With Ayurveda Deepika Commentary by Chakrapanidatta, Edited By Vaidya Yadavji Trikamaji Acharya,Chikitsa sthana, Chapter 10, shloka 27, Published by Satyabhamabai Pandurang, For the Nirnaya Sagar Press, Bombay, Third edition, Pg No 476.

24. Agnivesa, Charaka Samhita, elaborated by Charaka and Drdhabala, With Ayurveda Deepika Commentary by Chakrapanidatta, Edited By Vaidya Yadavji Trikamaji Acharya, Chikitsa sthana, Chapter 10, shloka 34, Published by Satyabhamabai Pandurang, For the Nirnaya Sagar Press, Bombay, Third edition, Pg No 476

25. Agnivesa, Charaka Samhita, elaborated by Charaka and Drdhabala, With Ayurveda Deepika Commentary by Chakrapanidatta, Edited By Vaidya Yadavji Trikamaji Acharya, Chikitsa sthana, Chapter 10, shloka 39, Published by Satyabhamabai Pandurang, For the Nirnaya Sagar Press, Bombay, Third edition, Pg No 476.

26. Agnivesa, Charaka Samhita, elaborated by Charaka and Drdhabala, With Ayurveda Deepika Commentary by Chakrapanidatta, Edited By Vaidya Yadavji Trikamaji Acharya, Chikitsa sthana, Chapter 17, shloka 123, Published by Satyabhamabai Pandurang, For the Nirnaya Sagar Press, Bombay, Third edition, Pg No 538.

27. Agnivesa, Charaka Samhita, elaborated by Charaka and Drdhabala, With Ayurveda Deepika Commentary by Chakrapanidatta, Edited By Vaidya Yadavji Trikamaji Acharya, Kalpa sthana, Chapter 1, shloka 23, Published by Satyabhamabai Pandurang, For the Nirnaya Sagar Press, Bombay, Third edition, Pg No 655.

28. Agnivesa, Charaka Samhita, elaborated by Charaka and Drdhabala, With Ayurveda Deepika Commentary by Chakrapanidatta, Edited By Vaidya Yadavji Trikamaji Acharya, Kalpa sthana, Chapter 4, shloka 16, Published by Satyabhamabai Pandurang,For the Nirnaya Sagar Press, Bombay, Third edition, Pg No 660.

29. Ch siddhi $4 / 20$ Agnivesa, Charaka Samhita, elaborated by Charaka and Drdhabala, With Ayurveda Deepika Commentary by Chakrapanidatta, Edited By Vaidya Yadavji Trikamaji Acharya, Siddhi sthana, Chapter 4, shloka 21 Published by Satyabhamabai Pandurang, For the Nirnaya Sagar Press, Bombay, Third edition, Pg No 699.

30. Vagbhata, Ashtanga Hridaya with commentary of Sarvangasundara of Arunadatta and Ayurveda Rasayana of Hemadri, Sutra sthana, Chapter 15, shloka 43, Chaukhamba Sanskrit Sansthan, Varanasi, Reprint, Pg No 239

31. Vagbhata, Ashtanga Samgraha, with Hindi Commentary, Volume 2, By Kaviraj Atrideva Gupta, Uttarasthana, Chapter 
24, shloka 4, Chowkhamba Krishnadasa Academy, Varanasi, Reprint 2016, Pg No. 273

32. Vagbhata, Ashtanga Hridaya with commentary of Sarvangasundara of Arunadatta and Ayurveda Rasayana of Hemadri, Uttara sthana, Chapter 20, shloka 4, Chaukhamba Sanskrit Sansthan, Varanasi, Reprint, Pg No 844)

33. Vrdha jeevaka, Kashyapa Samhitha, Revised by Vtsya, With Vidyotini Hindi Commenatry By Ayurvedalankara Sri Satyapala Bhishagacharya, Kalpa Sthanam, Dhupa Kalpa Adhyaya, Shloka 15?, published byJaya Krishna Das Gupta, The Chowkhamba Sanskrit Series Office, Page no 17

34. Dhanwantari Nighantu, Chandanadi Varga, shloka 70,71, Pg 103

35. Shodhala nighantu, Copyright (C) Central Council for Research in Ayurvedic Sciences (CCRAS), New Delhi, Designed and Developed by National Institute of Indian Medical Heritage (NIIMH), Hyderabad, http://niimh.nic.in/ebooks/eNighantu/shodhalanighantu/?mod=search\&searchText=corak a

36. Priyavrit Sharma, Kaiyyadeva Nighantu, Aushadhi Varga, Drug no 428, Shloka 1383- 1385, Chaukhamba Orientalia, Varanasi, Page 256

37. Khemraj Shree Krishnadasa, Shaligrama Nighantu, Karpooradi Varga, Shree Venkateshwara Press, Mumbai, Page 61

38. Abhidhanamanjari, Shloka 379,395, 892,44, Copyright (C) Central Council for Research in Ayurvedic Sciences (CCRAS), New Delhi, Designed and Developed by National Institute of Indian Medical Heritage (NIIMH), Hyderabad, http://niimh.nic.in/ebooks/e-

Nighantu/abhidhanamanjari/?mod=read $\& \mathrm{~h}=$ coraka

39. Abhidhanaratnamala, Chapter 5, Shloka 2,61, Copyright $\mathbb{C}$ Central Council for Research in Ayurvedic Sciences (CCRAS), New Delhi, Designed and Developed by National Institute of Indian Medical Heritage (NIIMH), Hyderabad http://niimh.nic.in/ebooks/e-

Nighantu/abhidhanaratnamala/ mod $=$ search\&searchText $=$ cor aka

40. Ashtanga nighantu, Chapter 25, Shloka 179, Copyright (C) Central Council for Research in Ayurvedic Sciences (CCRAS), New Delhi, Designed and Developed by National Institute of Indian Medical Heritage (NIIMH), Hyderabad http://niimh.nic.in/ebooks/e-

Nighantu/ashtanganighantu/ mod $=$ search\&searchText=corak a

41. Madanadi nighantu, Chapter 31, Shloka 9, Copyright (C) Central Council for Research in Ayurvedic Sciences (CCRAS), New Delhi, Designed and Developed by National Institute of Indian Medical Heritage (NIIMH), Hyderabad http://niimh.nic.in/ebooks/e-

Nighantu/madanadinighantu/ mod $=$ search\&searchText=cora ka\#

42. Sarasvati nighantu, Chapter 5, Shloka 28,29, Copyright (C) Central Council for Research in Ayurvedic Sciences (CCRAS), New Delhi, Designed and Developed by National Institute of Indian Medical Heritage (NIIMH), Hyderabad http://niimh.nic.in/ebooks/e-

Nighantu/sarasvatinighantu/ $\mathrm{mod}=$ search\&searchText=corak a

43. Soushruta nighantu, Shloka 174, Copyright (C) Central Council for Research in Ayurvedic Sciences (CCRAS), New Delhi, Designed and Developed by National Institute of Indian Medical Heritage (NIIMH), Hyderabad http://niimh.nic.in/ebooks/e-

Nighantu/soushrutanighatu/?mod=read\&h=coraka

44. Raja Nighnatu, Copyright (C) Central Council for Research in Ayurvedic Sciences (CCRAS), New Delhi, Designed and Developed by National Institute of Indian Medical Heritage (NIIMH), Hyderabad http://niimh.nic.in/ebooks/eNighantu/rajanighantu/?mod=read\&h=coraka

45. Madanapala nighantu, Copyright (C) Central Council for Research in Ayurvedic Sciences (CCRAS), New Delhi, Designed and Developed by National Institute of Indian Medical Heritage (NIIMH), Hyderabad, http://niimh.nic.in/ebooks/eNighantu/madanapalanighantu/ $\mathrm{mod}=$ read $\& \mathrm{~h}=$ coraka

46. Bhavamisra, Bhavaprakasha Nighantu, Commentary by Dr K.C. Chunekar, Chaukhambha Bharati Academy, Varanasi,1982, 6th edition, Page 254-255

47. The Ayurvedic Pharmacopoeia of India, Part- i Volume V, Government Of India Ministry of Health And Family Welfare, Department Of AYUSH, Page 18

48. Khetwal, K. S., Pathak, S. K., Sajwan, K., Pandey, B., Adhikari, A., \& Tkachev, A. V. (2004). Constituents of highaltitude Himalayan herb Angelica glauca.

49. Thappa, R. K., Kaul, P., Chisti, A. M., Kapahi, B. K., Suri, O. P., \& Agarwal, S. G. (2005). Variability in the essential oil of Angelica glauca Edgew of different geographical regions. Journal of Essential Oil Research, 17(4), 361-363.

50. Irshad, M.; Rehman, H.U.; Shahid, M.; Aziz, S.; Ghous, T. Antioxidant, antimicrobial and phytotoxic activities of essential oil of Angelica glauca. Asian J. Chem. 2011, 23, 19471951.

51. Agnihotri, V.K.; Thappa, R.K.; Meena, B.; Kapahi, B.K.; Saxena, R.K.; Qazi, G.N.; Agarwal, S.G. Essential oil composition of aerial parts of Angelica glauca growing wild in North-West Himalaya (India). Phytochemistry 2004, 65, 2411-2413. [CrossRef] [PubMed]

52. Purohit, V.K.; Andola, H.C.; Haider, S.Z.; Tiwari, D.; Bahuguna, Y.M.; Gairola, K.C.; Arunachalam, K. Essential Oil Constituents of Angelica glauca Edgew. Roots: An Endangered Species from Uttarakhand Himalaya (India). Natl. Acad. Sci. Lett. 2015, 38, 445-447. [CrossRef]

53. Sharma, S., Rasal, V. P., Patil, P. A., \& Joshi, R. K. (2017). Effect of Angelica glauca essential oil on allergic airway changes induced by histamine and ovalbumin in experimental animals. Indian journal of pharmacology, 49(1), 55.

54. Singh, G., Chandra, N., Lingwal, S., Bisht, M. P. S., \& Tiwari, L. M. (2020). Distribution and Threat Assessment of an Endemic and Endangered Species Angelica glauca in High Ranges of Western Himalaya. Journal of Herbs, Spices \& Medicinal Plants, 1-11. 
55. Sood, M., Aziem, S., Iqbal, K., Hussain, A., \& Mahato, S. (2019). Economic potential of Angelica glauca Edgew: an endangered plant of western Himalaya. G-Journal of Environmental Science and Technology, 6(5), 28-30.

\section{Source of Support: Nil \\ Conflict of Interest: None Declared}

How to cite this URL: Sangeetha G. Pillai et al: A Review On An Endangered Himalayan Medicinal Aromatic Plant Choraka (Angelica Glauca Edgew). International Ayurvedic Medical Journal \{online\} 2020 \{cited September, 2020\} Available from:

http://www.iamj.in/posts/images/upload/4508_4515.pdf 